\title{
Aksesibilitas Dalam Penyediaan Fasilitas Pelayanan SIM-D Bagi Penyandang Disabilitas Di Satpas Colombo Kota Surabaya
}

\author{
Amara Ayu Fadilla ${ }^{1}$, Cahya Fitri Widiyantari' ${ }^{2}$, Tukiman Tukiman ${ }^{3}$ \\ ${ }^{1,2,3}$ Program Studi Administrasi Publik, Universitas Pembangunan Nasional Veteran, \\ Jawa Timur

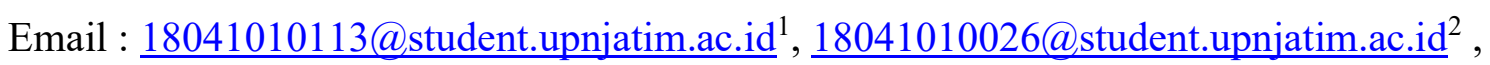 \\ tukiman upnjatim@yahoo.com ${ }^{3}$
}

Dikirim : 10 Mei 2021 | Direvisi : 26 Mei 2021 | Diterima : 31 Mei 2021

\begin{abstract}
ABSTRAK
Penelitian ini bertujuan untuk mengetahui bentuk tanggung jawab SATPAS Colombo dalam memberikan pelayanan prima terhadap jaminan aksesibilitas bagi penyandang disabilitas sesuai dengan peraturan perundang-undangan dan aksesibilitas terhadap fasilitas pelayanan publik bagi penyandang disabilitas. Aksesibilitas merupakan kemudahan yang disediakan untuk seluruh orang termasuk penyandang cacat serta lanjut usia guna mewujudkan kesamaan peluang dalam seluruh aspek kehidupan serta penghidupan (Peraturan Menteri Pekerjaan Umum Nomor. 30/ PRT/ M/ 2006, 2006). Penelitian ini menggunakan metode deskriptif kualitatif, pengumpulan informasi dilakukan dengan memakai metode purposive sampling serta dengan tata cara observasi, dokumentasi, serta wawancara. SATPAS Colombo Kota Surabaya telah memiliki dan memenuhi bermacam sarana untuk penyandang disabilitas. Infrastruktur semacam penyediaan fasilitas prasarana sarana pelayanan publik permohonan pengurusan SIM D, parkir khusus untuk penyandang disabilitas, toilet khusus penyandang difabel, dan ruang tunggu khusus, tetapi belum seluruhnya memenuhi aksesibilitas untuk penyandang disabilitas. Sedangkan penyandang disabilitas juga termasuk masyarakat yang berhak memperoleh kemudahan akses pelayanan publik, sama semacam masyarakat yang lain. Hasil dari penelitian ini adalah telah terpenuhinya beberapa sarana dan prasarana yang memadai untuk penyandang disabilitas, akan tetapi masih memerlukan petugas khusus yang melayani penyandang disabilitas agar pelayanan dapat terlaksana dengan lebih maksimal.
\end{abstract}

Kata Kunci: Aksesibilitas; Pelayanan Publik; Pelayanan Disabilitas; Aksesibilitas Disabilitas

\section{ABSTRACT}

This study aims to determine the form of SATPAS Colombo responsibility in providing excellent service to guarantee accessibility for persons with disabilities in accordance with statutory regulations and accessibility to public service facilities for persons with disabilities. Accessibility is an convenience provided for all people, including persons with disabilities and the elderly in order to realize equal opportunities in all aspects of life and livelihood (Minister of Public Works Regulation No. 30 / PRT / M / 2006, 2006). This research uses descriptive qualitative research procedures, information collection is carried out using purposive sampling method and by means of observation, documentation, and interviews. SATPAS 
Colombo Kota Surabaya already has various facilities for people with disabilities. Infrastructure such as the provision of infrastructure facilities for public service applications for SIM D management, special parking for people with disabilities, special toilets, special waiting rooms, but not all of them meet the accessibility for persons with disabilities. Meanwhile, people with disabilities are also people who have the right to have easy access to public services, just like any other community. The results of this study are that several adequate facilities and infrastructure for persons with disabilities have been fulfilled, but still require special officers to serve persons with disabilities so that services can be carried out more optimally.

Keywords: Accessibility; Public Services; Disabled Services; Accessibility.

\section{PENDAHULUAN}

Banyak masyarakat yang tidak menyadari bahwa kehidupan dapat berjalan tidak seperti yang diharapkan, khususnya bagi mereka yang terpinggirkan. Kelompok-kelompok yang terpinggirkan secara ekonomi, sosial, maupun fisik seringkali tidak mendapatkan perhatian yang layak. Khususnya pada masyarakat yang memiliki keterbatasan yang biasa disebut dengan istilah penyandang cacat atau disabilitas. Istilah ini lebih berkonotasi negatif sehingga dampaknya mereka sering diabaikan bahkan dijauhkan dari kegiatan masyarakat, sehingga kurang berpastisipasi dalam kegiatan sosial. Cacat tubuh adalah bagian dari kehidupan manusia. Hampir setiap orang bisa jadi mengalami disabilitas secara sementara atau permanen pada suatu saat dalam hidup mereka. Lebih dari satu miliar manusia, yaitu sekitar $15 \%$ dari populasi global, hidup dengan beberapa bentuk disabilitas dan jumlah ini terus meningkat. Disabilitas merupakan efek dari kondisi kesehatan tertentu seperti cerebral palsy, down syndrome, kecelakaan, bawaan lahir, dan depresi serta faktor personal dan lingkungan. Hal ini membuat penyandang disabilitas seperti "dipinggirkan" termasuk beberapa dampak negatif seperti tidak dapat diaksesnya transportasi dan bangunan umum, serta dukungan sosial yang terbatas.

Sebagai salah satu negara yang mempunyai jumlah penduduk yang banyak di dunia, Indonesia sudah mengamanatkan jaminan aksesibilitas untuk penyandang kebutuhan khusus yang salah satunya teruji lewat terdapatnya UU No 36 Tahun 2009 tentang Kesehatan yang memuat tentang Kesehatan Lanjut Usia serta Kesehatan untuk Penyandang Cacat, dimana dalam UU tersebut dinyatakan jika upaya pemeliharaan kesehatan penyandang cacat sebisa mungkin wajib diperuntukan demi terciptanya tujuan hidup sehat serta produktif secara sosial, murah, serta bermartabat. Penyediaan fasilitas serta prasarana yang mencukupi untuk para kaum disabilitas diharapkan akan sanggup tingkatkan kemampuan dan kedudukan disabilitas (Lustiyati \& Rahmuniyati, 2019).

Orang dengan disabilitas kebanyakan memiliki hasil kesehatan yang kurang baik, memiliki akses yang lebih sedikit ke pendidikan dan kesempatan kerja, dan lebih sering ditemui hidup dalam faktor kemiskinan dibandingkan dengan mereka yang tidak memiliki disabilitas. Penyandang disabilitas sering kali tidak diberi kesempatan untuk bekerja, bersekolah, dan berpartisipasi penuh dalam masyarakat yang menciptakan hambatan bagi kemakmuran dan kesejahteraan mereka. Seringkali penyandang disabilitas tidak menerima layanan kesehatan 
dasar yang mereka butuhkan. Bukti menunjukkan bahwa setengah dari penyandang disabilitas tidak mampu membayar perawatan kesehatan. Beberapa kemajuan telah dibuat untuk membuat dunia lebih mudah diakses oleh orang-orang yang hidup dengan disabilitas, akan tetapi lebih banyak pekerjaan yang dibutuhkan untuk membantu dalam memenuhi kebutuhan mereka (Disability, n.d.)

Menurut Pasal 1 Ayat 1 Peraturan Pemerintah Republik Indonesia Nomor 42 Tahun 2020 tentang Aksesibilitas Terhadap Permukiman, Pelayanan Publik, dan Pelindungan dari Bencana Bagi Penyandang Disabilitas, "Penyandang disabiltas adalah setiap orang yang mengalami keterbatasan fisik, intelektual, mental, atau sensorik dalam jangka waktu lama yang dalam berinteraksi dengan lingkungan dapat mengalami hambatan dan kesulitan untuk berpartisipasi secara penuh dan efektif sebagai warga negara lainnya berdasarkan kesamaan hak". Penyandang kebutuhan khusus belum menemukan tempat di mata publik, kehadirannya masih ditatap sebelah mata. Sebab terdapatnya keterbatasan yang dipunyai, jutru membuat mereka disangka sebagai kelompok yang lemah, tidak berdaya serta butuh memperoleh belas kasihan. Hak- hak mereka selaku manusia juga pula kerapkali diabaikan. Mulai dari hak untuk hidup, hak untuk mendapatkan pelayanan pembelajaran serta kesehatan sampai hak kemudahan dalam mengakses sarana umum. Sikap diskriminatif terhadap penyandang disabilitas tersebut biasanya disebabkan oleh uraian negatif tentang apa itu disabilitas serta siapa itu penyandang disabilitas.

Uraian negatif tentang disabilitas serta penyandang disabilitas tersebut antara lain bersumber dari pola pikir warga yang berkomentar kalau suatu yang berbeda bukanlah wajar. Orang- orang yang penampilan ataupun badannya nampak maupun ditatap selaku "berbeda" dari yang dikira oleh warga selaku perihal yang wajar, hendak dikira selaku yang tidak diidamkan serta tidak bisa diterima selaku bagian dari warga. Pemberian cap negatif selaku "berbeda" dari yang diterima selaku perihal yang wajar ialah sesuatu proses stigmatisasi. Perilaku serta sikap diskriminatif tersebut hendak timbul apabila stigmatisasi ataupun pemberian cap negatif tersebut bersinambung dengan membagikan perbandingan berbentuk pembelahan secara paksa serta bertabiat menghalangi, ataupun melaksanakan aksi pengeluaran sebab dikira bukan bagian setara, apalagi dinilai kurang/ tidak bernilai secara sosial (Widinarsih, 2019).

PBB mengatakan bahwa penyandang disabilitas hadapi kesehatan yang lebih kurang baik, mempunyai prestasi yang lebih rendah, memperoleh kesempatan ekonomi lebih sedikit, dan terletak pada tingkatan kemiskinan yang lebih besar dibandingkan warga pada biasanya. Perihal ini diakibatkan oleh adanya hambatan- hambatan yang dialami, dan masih belum memadainya pemberian layanan yang sudah ada untuk kalangan penyandang disabilitas semacam teknologi data serta transportasi(“Difabel Masih Jadi Anak Tiri," 2019). Kendalakendala tersebut sebenarnya dapat diatasi dengan menyediakan suatu kebijakan, lingkungan fisik, dan sikap sosial yang anti diskriminasi. Sebab, manusia dengan fisiknya yang kurang sempurna berhak mendapatkan pelayanan yang setara dengan orang-orang lainnya. Sebab pada dasarnya penyandang disabilitas hanya perlu diberi fasilitas yang lebih menunjang, bukan diistimewakan.

Namun, pada kenyataannya seringkali berbanding terbalik dengan harapan. Meskipun hak-hak warga disabilitas telah dmendapatkan jaminan di dalam Undang-Undang Nomor 8 
Tahun 2016 tentang Penyandang Disabilitas, namun Indonesia masih belum bisa maksimal dalam memenuhi hak tersebut. Penyandang disabilitas masih belum mendapatkan hak-hak dasar mereka, seperti dalam hal mobilitas, akses pekerjaan yang layak, akses pendidikan, hak berwisata, hingga perlindungan hukum. Meskipun termasuk dalam golongan minoritas, keberadaan penyandang disabilitas suatu negara seharusnya tetap dijamin keberlangsungan hidupnya, karena penyandang disabilitas juga merupakan warga negara yang perlu dijamin kesejahteraan hidup dan juga kesejahteraan sosialnya.

Penyandang disabilitas harus memiliki perlakuan kesetaraan hak dan kewajiban yang sama tanpa adanya satu pembedaan sedikitpun. Karena sudah selayaknya penyandang disabilitas mendapatkan fasilitas penunjang sebagai salah satu bentuk upaya perlindungan dari kerentanan terhadap tindakan-tindakan diskriminasi serta sebagai salah satu bentuk upaya dalam memberikan perlindungan dengan memaksimalkan penghormatan, pemajuan, perlindungan dan pemenuhan HAM (Pratomo \& Fadli, n.d.). Dalam hal berlalu lintas, penyandang disabilitas juga harus mendapatkan fasilitas yang khusus, maka dari itu tentunya diperlukan kebijakan yang dapat mengatur tentang perlakuan khusus terhadap penyandang disabilitas. Contoh aturan tersebut tercantum di dalam Undang-undang No. 22 tahun 2009 tentang Lalu Lintas dan Angkutan Jalan (LLAJ), yang selanjutnya disebut dengan UU LLAJ Pasal 80 huruf e mengenai keberlakuan SIM D bagi kendaraan khusus penyandang Disabilitas. Layanan SIM D bagi penyandang disabilitas diatur dalam UU LLAJ Pasal 80 Huruf(e). Proses perolehan dan pengurusan SIM D bagi penyandang disabilitas pada dasarnya sama dengan proses perolehan SIM bagi masyarakat umum.

Pertama pemohon diwajibkan untuk melakukan cek kesehatan, kemudian melaksanakan ujian tes tertulis lalu dilanjutkan dengan tes praktek. Prosedur dalam mendapatkan SIM D tetap sama karena pemohon dari kalangan penyandang disabilitas juga diharuskan memiliki kemampuan berkendara serta memiliki pengendalian emosi yang baik dalam berkendara seperti masyarakat lainya. Namun, dalam prakteknya masih ditemukan hambatan yang dialami oleh penyandang disabilitas dalam memperoleh SIM D, sehingga sebagian dari mereka masih belum memiliki SIM D sebagai lisensi untuk berkendara di jalan raya (Budiman \& Astuti, 2019).

Dari penjelasan diatas menunjukkan bahwa Pemerintah telah berusaha untuk memaksimalkan penghormatan pemajuan perlindungan dan pemenuhan HAM bagi disabilitas dengan memberlakukan regulasi dalam pembuatan SIM D yang dilakukan oleh Satlantas Polrestabes Surabaya di Satpas Colombo. Namun peneliti ingin mengetahui lebih lanjut mengenai pelayanan yang diberikan oleh petugas pemberi layanan kepada penyandang disabilitas, sehingga peneliti tertarik untuk mengetahui kendala apa saja yang dialami dalam proses pelayanan SIM D agar dapat mendorong kepuasan pelayanan yang diberikan oleh Satpas Colombo Surabaya menjadi optimal dan lebih baik, serta upaya apa saja yang telah dilakukan oleh Satlantas Polrestabes Surabaya dalam memberi pengetahuan ke masyarakat mengenai adanya program SIM khusus difabel.

Aksesibilitas merupakan isu penting dalam penerapan sarana prasarana bagi disabilitas. Dalam perkembangannya, telah terdapat banyak tempat-tempat umum yang sudah mulai memperhatikan aksesibilitas (Widi \& Nirwansyah, 2013). Menurut Peraturan Menteri Pekerjaan Umum No 30 Tahun 2006, Aksesibilitas adalah kemudahan yang disediakan bagi 
semua orang termasuk penyandang disabilitas dan masyarakat lanjut usia untuk mewujudkan kesamaan kesempatan dan kesetaraan dalam segala aspek kehidupan dan penghidupan. Aksesibilitas merupakan syarat penting bagi disabilitas untuk menjalankan aktivitas kehidupannya sesuai dengan standar yang telah ditetapkan oleh pemerintah (Priscyllia, n.d.) Dalam ketentuan UU No. 8 Tahun 2016 Pasal 1 Ayat (8) tentang Penyandang Disabilitas memberikan definisi dari aksesibilitas, yaitu Aksesibilitas adalah kemudahan yang disediakan untuk Penyandang Disabilitas guna mewujudkan Kesamaan Kesempatan. Pasal 1 ayat 2 UU No. 8 Tahun 2016 tentang Penyandang Disabilitas dinyatakan bahwa Kesamaan Kesempatan adalah keadaan yang memberikan peluang dan menyediakan akses kepada Penyandang Disabilitas untuk menyalurkan potensi dalam segala aspek penyelenggaraan negara dan masyarakat.

Menurut Lijian Poltak Sinambela, pada dasarnya setiap manusia membutuhkan pelayanan, bahkan dapat pula dikatakan bahwa pelayanan tidak dapat dipisahkan dari kehidupan manusia. Sampara berpendapat, pelayanan adalah suatu kegiatan yang terjadi dalam interaksi langsung antara seseorang dengan orang lain atau secara fisik, dan menyediakan kepuasan masyarakat (Sinambela, 2010). Sementara itu, istilah publik berasal dari Bahasa Inggris public yang berarti umum, masyarakat, Negara (Sinambela, 2010). Pelayanan publik diartikan sebagai suatu kegiatan yang dilakukan oleh pemerintah sebagai pemangku kebijakan terhadap sejumlah manusia yang memiliki setiap kegiatan yang menguntungkan dalam suatu kumpulan atau kesatuan, dan menawarkan kepuasan meskipun hasilnya tidak terikat pada suatu produk secara fisik (Pasolong, 2007).

Berdasarkan Ketetapan MPR Nomor XI/MPR 1998 tentang Penyelenggaraan Negara yang Bersih dan Bebas dari KKN (Korupsi, Kolusi dan Nepotisme) memberikan amanat kepada Aparatur Negara untuk mampu menjalankan tugas dan fungsinya secara profesional, produktif, transparan, dan bebas dari KKN. Salah satu tugas dan fungsi Aparatur Negara adalah memberikan pelayanan publik yang prima kepada masyarakat. Karena dalam menghadapi era global yang penuh dengan tantangan dan peluang, Aparatur Negara hendaknya memberikan pelayanan yang sebaik-baiknya, serta berorientasi pada kebutuhan dan kepuasan masyarakat sebagai penerima pelayanan.

Pelayanan prima bertujuan untuk memberikan pelayanan yang nantinya dapat memenuhi dan memuaskan masyarakat serta memberikan fokus pelayanan penuh kepada masyarakat. Pelayanan prima di dalam sektor publik didasarkan pada pernyataan bahwa "pelayanan juga merupakan suatu pemberdayaan bagi masyarakat", yang artinya pelayanan yang memiliki tujuan untuk memberdayakan masyarakat, dan bukan memperdayakan atau membebani masyarakat, tetapi memberdayakan masyarakat untuk meningkatkan kepercayaan (trust) kepada pemerintah sebagai pemberi pelayanan utama. Dalam memberikan pelayanan kepada masyarakat diperlukan pula adanya pengukuran kinerja pelayanan publik yang berfungsi sebagai penilaian atas keberhasilan atau kegagalan pelaksanaan kegiatan, program atau kebijakan sesuai dengan sasaran dan tujuan yang telah ditetapkan dalam rangka mewujudkan visi dan misi organisasi pemberi layanan. Pengukuran kinerja mencakup penetapan indikator kinerja serta penetapan indikator kerja pelayanan publik. Dengan istilah lain, pengukuran kinerja merupakan metode untuk menilai kemajuan atau hasil yang telah dicapai untuk dibandingkan dengan tujuan yang telah ditetapkan (Mukarom \& Laksana, 2015). 
Pelayanan publik tentunya harus mudah diakses oleh seluruh warga negara tanpa terkecuali, termasuk penyandang disabilitas. Penyandang disabilitas seringkali dianggap merepotkan karena memerlukan perlakuan dan perhatian lebih dalam menjalankan hidupnya. Namun tetap saja, penyandang disabilitas adalah bagian dari warga negara yang memiliki hak yang sama dengan orang lain. Salah satu penunjang kemandirian penyandang disabilitas yang diberikan adalah diberikannya SIM khusus penyandang disabilitas, agar dapat beraktifitas dengan mobilisasi yang lebih mudah, aman, dan memiliki hak dan kewajiban yang sama dengan masyarakat pada umumnya. Namun, masih terdapat kendala yang ditemui peneliti mengenai pelaksanaan pemenuhan kebutuhan penyandang disabilitas dalam bidang pelayanan SIM D yaitu seperti tidak tersedianya petugas khusus yang melayani penyandang disabilitas tuna wicara atau tuna rungu yang menguasai bahasa isyarat, sehingga masih belum dapat memberi pelayanan yang prima. Selain itu, minimnya pengetahuan pemahaman mengenai tata tertib berlalu lintas oleh pemohon SIM D juga menjadi salah satu hambatan dari tercapainya pelayanan yang maksimal. Tujuan dari penelitian ini adalah untuk mengetahui bentuk tanggung jawab Satpas Colombo dalam memberikan pelayanan prima terhadap jaminan aksesibilitas bagi penyandang disabilitas sesuai dengan peraturan perundang-undangan dan aksesibilitas terhadap fasilitas pelayanan publik bagi penyandang disabilitas. Hasil dari penelitian ini nantinya dapat menjadi masukan bagi Satpas Colombo Surabaya dalam memberikan pelayanan SIM D kepada penyandang disabilitas.

\section{METODE PENELITIAN}

Metode yang digunakan dalam penelitian ini adalah penelitian deskriptif kualitatif. Terkait dengan rumusan masalah yang ada maka penyusunan menggunakan jenis penelitian kualitatif, yakni penelitian yang dilakukan langsung di lapangan. Penelitian dilakukan secara langsung ke obyek penelitian yakni Satpas Colombo Surabaya yang berlokasi di Jalan Ikan Kerapu no 2-4 Surabaya untuk mendapatkan data-data yang valid dan relevan mengenai pelayanan pengurusan SIM D khusus penyandang disabilitas. Metode deskriptif adalah riset yang diadakan untuk memperoleh fakta tentang gejala atas permasalahan yang timbul (Kadji, 2016). Sedangkan penelitian kualitatif merupakan metode-metode untuk mengeksplorasi dan memahami makna yang oleh sejumlah individu atau sekelompok orang dianggap berasal dari masalah sosial atau kemanusiaan (Creswell, 2010).

Jenis dan sumber data yang digunakan adalah data primer yaitu melakukan penelitian secara langsung di lapangan dengan melakukan wawancara kepada Bagian Urusan Administrasi Satlantas Polrestabes Surabaya. Data sekunder diperoleh melalui buku-buku, jurnal yang didapat dari website jurnal nasional maupun internasional resmi yang berkenaan dengan penelitian ini (Kadji, 2016). Untuk mengumpulkan data primer dan data sekunder tersebut peneliti menggunakan teknik pengumpulan data dengan wawancara, dokumentasi, dan mengumpulkan data dari jurnal dan buku resmi.

\section{HASIL DAN PEMBAHASAN}

Dalam berkendara dan berlalu lintas, penyandang disabilitas telah diberikan peraturan khusus oleh Pemerintah, yaitu salah satunya dengan fasilitasi penggunaan SIM D bagi penyandang disabilitas. Agar dapat memanfaatkan dan memiliki kendaraan agar sesuai dengan 
peraturan yang ada, masyarakat harus memiliki kelengkapan dokumen administrasi berupa Bukti Kepemilikan Kendaraan Bermotor (BPKB), Surat Tanda Nomor Kendaraan (STNK), dan Surat Izin Mengemudi (SIM). Sebagai lembaga yang berwenang dalam proses pengurusan SIM D, Polisi telah melaksanakan kebijakan terkait yang sesuai dengan perundang-undangan yang telah ada. Berdasarkan hasil wawancara dengan Bapak Okta selaku petugas Urusan Administrasi Satlantas Polrestabes Surabaya, pelayanan pengurusan SIM D bagi penyandang disabilitas di Satpas Colombo Kota Surabaya telah memberikan fasilitas yang memadai kepada penyandang disabilitas, seperti ramp tangga, jalur difabel, toilet difabel, dan loket khusus difabel.

Namun mengenai jumlah pendaftar tidak bisa dipastikan berapa banyaknya tiap bulan, karena tidak menentunya partisipasi masyarakat dalam pengurusan SIM D, sepertu contohnya pada bulan Maret 2021 Satpas Colombo hanya melayani satu pendaftar SIM D. Padahal sosialisasi telah dilakukan oleh Satlantas Polrestabes Surabaya melalui radio, koran, media sosial, baliho, dan website sehingga harusnya mendapat atensi dari masyarakat, namun hal tersebut tidak dilakukan secara rutin sehingga kurang berdampak luas. Selain itu, hambatan lain yang ditemukan oleh peneliti adalah belum adanya petugas khusus yang menguasai bahasa isyarat untuk penyandang disabilitas tuna rungu dan tuna wicara sebagaimana yang tercantum dalam PP no 42 tahun 2020 tentang Masyarakat Berkebutuhan Khusus, dimana tercantum bahwa di sentra-sentra pelayanan publik harus terdapat petugas yang bisa bahasa isyarat. Partisipasi penyandang disabilitas dalam pengurusan SIM D dibatasi pada penyandang disabilitas fisik, terkecuali tuna netra.

Pengurusan SIM D khusus difabel juga melakukan test drive dengan kendaraan yang dibawa oleh pendaftar, karena kendaraan pasti telah disesuaikan dengan kondisi yang dialami penyandang disabilitas. Namun pihak Satpas Colombo tidak memberi standarisasi bagaimana kendaraan harus dibuat, dan belum ada peraturan yang mengatur tentang modifikasi kendaraan bermotor yang dimiliki penyandang disabilitas. Nantinya, akan ada klasifikasi sendiri bagi pendaftar SIM D yaitu bagi pengendara sepeda motor (D1) dan pengendara mobil (D2) namun hal tersebut masih dipertimbangkan dan dibahas lagi. Dalam penelitian ini, peneliti menggunakan indikator kualitas pelayanan prima dalam buku "Reformasi Pelayanan Publik: Teori, Kebijakan dan Implementasi” karya Lijan Poltak Sinambela. Dalam teorinya, tujuan dari pelayanan publik adalah memberikan kepuasan kepada masyarakat. Dalam mencapai kepuasan tersebut, dituntut pemberian kualitas pelayanan prima yang dinilai dari :

a. Transparan; Pelayanan yang diberikan oleh petugas pemberi pelayanan kepada masyarakat harus bersifat terbuka, simple, dan dapat diakses oleh seluruh masyarakat yang membutuhkan dan difasilitasi secara memadai serta mudah dimengerti baik dari sarana maupun prasarana. Dalam hal ini, pelayanan SIM D untuk penyandang disabilitas di Satpas Colombo sudah bersifat terbuka, mudah dan dapat diakses, dan diberi fasilitas yang memadai. Hal ini dibuktikan dengan petugas yang membantu calon pendaftar SIM D dari awal proses registrasi hingga akhir dan dengan sigap membantu penyandang disabilitas yang hendak melakukan pengurusan SIM D baik perpanjangan ataupun pembuatan baru.

b. Akuntabilitas; Pemberian layanan yang dapat dipertanggung jawabkan sesuai dengan peraturan yang berlaku. Dalam hal ini, penerapan aturan tercantum dalam UU No. 22 tahun 2009 tentang Lalu Lintas dan Angkutan Jalan (LLAJ), yang selanjutnya disebut UU LLAJ 
Pasal 80 mengenai legalitas SIM D sebagai kendaraan khusus penyandang disabilitas. Namun, dalam penerapan pada Peraturan Pemerintah RI no 42 Tahun 2020 Tentang Aksesibilitas Terhadap Permukiman, Pelayanan Publik, Dan Pelindungan Dari Bencana Bagi Penyandang Disabilitas pasal 18 dimana Satpas Colombo belum memberikan petugas yang memberi pendampingan dan penerjemahan kepada masyarakat penyandang disabilitas sehingga belum bisa memaksimalkan pelayanan yang diberikan.

c. Kondisional; Pemberian layanan yang selaras dengan kondisi dan kemampuan pemberi dan penerima pelayanan dengan tetap bertuju pada prinsip efektivitas dan efisiensi. Dalam pelaksanaannya, petugas pemberi pelayanan di Satpas Colombo selalu sigap saat ada penyandang disabilitas yang datang akan melakukan pengurusan SIM D dengan langsung dibantu dalam proses pengurusannya tanpa mengikuti antrian karena lebih di prioritaskan dalam pemberian layanan. Prioritas pemberian layanan diberikan kepada lansia, ibu hamil, dan bagi penyandang disabilitas.

d. Partisipatif; Pemberian pelayanan yang dapat mendorong keikutsertaan masyarakat dalam penyelenggaraan pelayanan publik dengan mengedepankan kebutuhan, aspirasi, dan harapan masyarakat. Satpas Colombo berusaha untuk memaksimalkan pemberian pelayanan publik untuk memenuhi kebutuhan masyarakat dalam mendapatkan haknya sebagai warga negara dengan tetap berpedoman pada Peraturan Perundang-Undangan agar terciptanya pelayanan yang dapat memberikan kepuasan bagi masyarakat, dan juga mendapatkan aspirasi yang lebih baik dari masyarakat.

e. Kesamaan Hak; Pemberian pelayanan yang tidak melakukan pembedaan dilihat dari segala aspek khususnya ras, golongan, suku, status sosial, dan sebagainya. Dalam implementasi yang telah dilakukan oleh Satpas Colombo telah dilakukan kesetaraan dalam memberikan pelayanan kepada masyarakat umum maupun bagi penyandang disabilitas. Namun, bagi penyandang disabilitas pelayanan yang diberikan lebih khusus dan ditunjang fasilitas serta sarana prasarananya yang bertujuan sebagai penunjang proses kelancaran bagi penyandang disabilitas dalam pengurusan SIM D.

f. Keseimbangan Hak dan Kewajiban; Pemberian pelayanan yang memikirkan aspek keadilan antara penerima dan pemberi pelayanan publik. Dalam pemberian pelayanan ini, Satpas Colombo telah memberikan pelayanan yang cukup memadai bagi pemohon pengurusan SIM, terlebih bagi pemohon SIM D. Sebagai bentuk keseimbangan keadilan yang didapatkan oleh kedua belah pihak, baik dari petugas pemberi pelayanan Satpas Colombo tentunya harus selalu memberikan pendampingan khusus dan memberikan sarana prasarana yang dapat menunjang kesetaraan pelayanan pembuatan SIM antara masyarakat umum maupun masyarakat penyandang disabilitas. Sehingga petugas sebagai pemberi pelayanan publik kepada masyarakat juga mendapatkan haknya dengan memberikan sarana prasarana dan perlindungan yang memadai bagi pemohon pengurusan SIM biasa maupun SIM D khusus bagi penyandang disabilitas, karena dengan diadakannya implementasi pembuatan SIM khusus penyandang disabilitas ini merupakan bentuk perwujudan negara dalam menerapkan sila ke-5 (lima) Pancasila, yaitu memberikan keadilan yang setara pada seluruh rakyat Indonesia. 


\section{KESIMPULAN}

Berdasarkan pada hasil penelitian diatas dapat diambil kesimpulan bahwa dalam pelaksanaan pelayanan pada pengurusan pembuatan maupun perpanjangan SIM D bagi penyandang disabilitas ini sudah mudah diakses dan terbuka. Hal ini terbukti dengan dukungan pemerintah memberikan kemudahan akses dan dukungan fasilitas sarana dan prasarana dalam menunjang pengurusan SIM D bagi penyandang disabilitas. Adanya layanan pengurusan SIM D merupakan sarana penunjang pemenuhan hak disabilitas, namun belum memenuhi PP no 42 tahun 2020 pasal 18 tentang penerjemahan dan asistensi yang mudah diakses di tempat pelayanan publik. Penyandang disabilitas menjadi prioritas dalam pelayanan pengurusan SIM dengan pendampingan penuh dari awal hingga akhir. Pemenuhan kebutuhan masyarakat dalam mendapatkan haknya sebagai warga negara sehingga dapat memberikan pelayanan yang bisa menciptakan kepuasan bagi masyarakat. Pemberian fasilitas dalam sarana prasarana khusus yang dilakukan oleh pihak Satpas Colombo sebagai bentuk pemenuhan hak bagi penyandang disabilitas saat proses pengurusan SIM D. Pemberian pelayanan yang berlandaskan pada sila ke 5 Pancasila, yaitu dengan menerapkan keadilan yang sama rata bagi seluruh masyarakat Indonesia, baik yang memiliki kebutuhan khusus maupun yang sehat secara fisik.

Berdasarkan hasil penelitian dan kesimpulan diatas, peneliti dapat memberi saran sebagai bahan pertimbangan bagi pihak instansi terkait agar dapat melakukan pemberian layanan yang lebih baik kepada masyarakat, khususnya pada pelaksanaan pelayanan dan pemenuhan hak dalam bidang pelayanan pengurusan SIM D untuk penyandang disabilitas di Satpas Colombo Surabaya, yaitu mengenai diperlukannya petugas penerjemah atau tenaga ahli penerjemah untuk penyandang disabilitas, sosialisasi yang dilakukan dengang berkesinambungan agar menumbuhkan minat partisipasi penyandang disabilitas dalam pengurusan dan pendaftaran SIM D. Diharapkan pihak pemberi layanan dapat meningkatkan pelayanan dengan menugaskan tenaga ahli untuk melakukan pemanduan dan penerjemahan Bahasa isyarat untuk menunjang pelayanan yang lebih baik.

\section{DAFTAR PUSTAKA}

Budiman, Z. A., \& Astuti, P. (2019). Implementasi Perolehan SIM D bagi penyandang Disabilitas di wilayah Surabaya. Novum: Jurnal Hukum, 6(2). https://doi.org/10.2674/novum.v6i2.30192

Creswell, J. W. (2010). Research design pendekatan kualitatif, kuantitatif, dan mixed. Yogyakarta: pustaka pelajar.

Difabel Masih Jadi Anak Tiri. (2019, December 3). ITS News. https://www.its.ac.id/news/2019/12/03/difabel-masih-jadi-anak-tiri/

Disability. (n.d.). Retrieved April 15, 2021, from https://www.who.int/westernpacific/healthtopics/disability

Kadji, Y. (2016). Metode Penelitian Ilmu Administrasi. Deepublish.

Lustiyati, E. D., \& Rahmuniyati, M. E. (2019). Aksesibilitas Sarana Sanitasi bagi Difabel di Tempat Transportasi Umum. Inklusi, 6(1), 93. https://doi.org/10.14421/ijds.060105

Mukarom, Z., \& Laksana, M. W. (2015). Membangun Kinerja Pelayanan Publik: Menuju Clean Goverment and Good Governance. Pustaka Setia.

Pasolong, H. (2007). Teori Administrasi Publik. CV Alfabeta. 
Pratomo, D. T. (2015). Pelaksanaan Perlindungan Hak Atas Pendidikan bagi Penyandang Disabilitas (People With Disability) di Universitas Negeri Gorontalo. Kumpulan Jurnal Mahasiswa Fakultas Hukum.

Priscyllia, F. (2016). Kajian Hukum Terhadap Fasilitas Pelayanan Publik Bagi Penyandang Disabilitas. Lex Crimen, 5(3).

Sinambela, L. P. (2010). Reformasi Pelayanan Publik; Teori, Kebijakan, dan Implementasi Cet. V, PT Bumi Aksara, Jakarta.

Widi, N. A., \& Nirwansyah, R. (2013). Penerapan aksesibilitas pada desain fasilitas pendidikan sekolah luar biasa. Jurnal Sains dan Seni ITS, 2(2), G20-G25.

Widinarsih, D. (2019). Penyandang disabilitas di indonesia: perkembangan istilah dan definisi. Jurnal Ilmu Kesejahteraan Sosial (Journal of Social Welfare), 20(2).

Peraturan Pemerintah RI No 42 Tahun 2020 Tentang Aksesibilitas Terhadap Pemukiman, Pelayanan Public, Dan Pelindungan Dari Bencana Bagi Penyandang Disabilitas

Permen Pekerjaan Umum No. 30/PRT/M/2006, 2006

UU Nomor 36 Tahun 2009 tentang Kesehatan tentang Kesehatan Lanjut Usia dan Penyandang Cacat

UU Nomor 8 Tahun 2016 tentang Penyandang Disabilitas

UU No. 22 tahun 2009 tentang Lalu Lintas dan Angkutan Jalan

UU No. 8 Tahun 2016 pasal 1 ayat (8) tentang Penyandang Disabilitas 